\title{
ELECTRODEPOSITION OF CdS THIN FILMS UNDER A MAGNETIC FIELD
}

\author{
ELEKTRIČNI NANOS TANKIH PLASTI CdS V MAGNETNEM \\ POLJU
}

\author{
Ayça Kiyak Yildirim \\ Bilecik Șeyh Edebali University, Vocational School of Higher Education, Bahçelievler District, Abdülhamit Han Boulevard, \\ 11230 Gülümbe/Bilecik, Turkey \\ ayca.kiyak@bilecik.edu.tr
}

Prejem rokopisa - received: 2018-04-21; sprejem za objavo - accepted for publication: 2018-06-14

doi:10.17222/mit.2018.079

\begin{abstract}
In this study, for the deposition of CdS thin films, electrodeposition was employed and some of the depositions were carried out under a magnetic field. The effects of the magnetic field were investigated in detail. It was understood from the film thicknesses that the magnetic field reduced the reaction rate from $7.39 \mathrm{~g} / \mathrm{cm}^{2} \mathrm{~s}$ to $3.66 \mathrm{~g} / \mathrm{cm}^{2} \mathrm{~s}$. X-Ray diffraction results showed that all the films were formed with a hexagonal structure. In addition, the crystallite sizes were calculated from these patterns and they varied between $35 \mathrm{~nm}$ and $15 \mathrm{~nm}$, depending on the reaction rate. Ultraviolet-visible spectroscopy was used for estimating the energy band gap. The energy band gaps varied from $2.30 \mathrm{eV}$ to $2.65 \mathrm{eV}$, depending on the reaction rates and, therefore, the magnetic field. When the scanning electron microscope images were examined, it was seen that the surfaces of the films that were obtained under the magnetic field were rougher.

Keywords: CdS; cadmium sulphide; electrodeposition; magnetic field
\end{abstract}

Avtorji so v tej študiji za izdelavo tankih CdS filmov (prevlek) uporabili električni nanos (depozicijo). V nekaterih primerih so v postopku uporabili tudi magnetno polje, katerega vpliv so natančno raziskali. Iz meritev debeline izdelanih prevlek so ugotovili, da magnetno polje zmanjša hitrost reakcije s the $7,39 \mathrm{~g} / \mathrm{cm}^{2} \mathrm{~s}$ na the $3,66 \mathrm{~g} / \mathrm{cm}^{2} \mathrm{~s}$. Raziskave $\mathrm{z}$ rentgensko difrakcijo so pokazale, da imajo vse izdelane prevleke heksagonalno strukturo. Dodatno so iz uklonskih slik izračunali velikost kristalitov; ta se je gibala med $35 \mathrm{~nm}$ in $15 \mathrm{~nm}$, odvisno od hitrosti reakcije. Za ocenitev energije prepovedanega valenčnega pasu so uporabili spektroskopijo v ultravijolični (UV) in vidni svetlobi. Le-ta se je gibala med 2,30 eV in 2,65 eV, odvisno od hitrosti reakcije oz. magnetnega polja. Z uporabo vrstičnega elektronskega mikroskopa (SEM) so ocenili hrapavost izdelanih prevlek. Ugotovili so, da so prevleke, izdelane v prisotnosti magnetnega polja, bolj grobe oziroma hrapave.

Ključne besede: CdS, kadmijev sulfid, elektrodepozicija, magnetno polje

\section{INTRODUCTION}

The electrodeposition of semiconductors has been widely explored and has been demonstrated by a larger number of researchers over the past years. This study focuses on electrodeposition because it is a relatively inexpensive and simple deposition technology. Typical deposition processes have been discussed in previous studies. Recently, there has been tremendous interest in nano-scale thin films and semiconductor particles due to their novel properties generated from quantum-confinement effects.

Cadmium sulfide $(\mathrm{CdS})$ is a direct n-type semiconductor and it has a band gap of about $2.4 \mathrm{eV}$ at room temperature and a large absorption coefficient of $4 \times 10^{4} \mathrm{~cm}^{-1}{ }^{2}$ II-VI semiconductors such as $\mathrm{CdS}, \mathrm{ZnS}$, $\mathrm{CdSe}$, and $\mathrm{ZnSe}$ are used as buffer layers in $\mathrm{Cu}(\mathrm{In}, \mathrm{Ga})(\mathrm{S}, \mathrm{Se})$ (CIGS) photovoltaic devices. Among these semiconductors, $\mathrm{CdS}$ is the most commonly used buffer layer and, thus, thin films of CdS have been used widely as window layers in solar cells and as absorber layers in $\mathrm{CdTe}, \mathrm{Cu}_{2} \mathrm{~S}$, or $\mathrm{CuInSe}{ }_{2}{ }^{3}$
So far, thin films of CdS have been deposited by various methods, such as chemical bath deposition, electrodeposition, chemical vapour deposition and spray pyrolysis. Among these methods, electrodeposition stands out as an attractive technique for the preparation of thin films in commercial quantities because of the fact that electrodeposition requires relatively cheap equipment, enables deposition on large areas and it is easy to control the growth parameters through the applied potential, current, $\mathrm{pH}$ and temperature of the bath. ${ }^{4}$

The reaction mechanism is proposed as follows: ${ }^{1}$

$$
\begin{gathered}
\mathrm{CdCl}_{2} \rightarrow \mathrm{Cd}^{2+}+2 \mathrm{Cl}^{-} \\
\mathrm{Na}_{2} \mathrm{~S}_{2} \mathrm{O}_{3}+\mathrm{H}_{2} \mathrm{O} \rightarrow \mathrm{S}_{2} \mathrm{O}_{3}^{2-}+\mathrm{Na}^{2} \mathrm{O}+2 \mathrm{H}^{+} \\
\mathrm{S}_{2} \mathrm{O}_{3}^{2-}+\mathrm{Cd}^{2+}+2 \mathrm{e}^{-} \rightarrow \mathrm{CdS}+\mathrm{S}_{2} \mathrm{O}_{3}^{2-}
\end{gathered}
$$

In the literature, there are various kinds of researches on electrodeposition of CdS thin films. But the effects of an external magnetic field have not been investigated so far. In one study, ${ }^{5}$ an external magnetic field was applied to the electrodeposition bath, but $\mathrm{ZnO}$ thin films were produced in the mentioned study. On the other hand, an external magnetic field is not a new application. In a previously study ${ }^{6}$ related to chemical bath deposition, an 
external magnetic field was applied and it is reported that the magnetic field reduced the reaction rate and it increased the diffraction peak intensity. In another study, ${ }^{7}$ the magnetic field reduced the crystallite size and increased the diffraction peak intensity. On the other hand, it is reported that the magnetic field reduced the grain size. ${ }^{8}$

In this work, the effects of the external magnetic field were investigated for the first time. It was understood that the magnetic field varied reaction rate; therefore, it varied the crystallite sizes of the films. Because there is a strong relationship between the crystallite size and the energy band gap, the energy band gaps of the films were varied between $2.30 \mathrm{eV}$ and $2.65 \mathrm{eV}$. It is estimated that magnetic force may divert ions in the electrolyte and this increases the number of collisions in the electrolyte. Thus, the current between the working electrode and the counter electrode may be reduced by a magnetic field. Besides, the external magnetic field had effects on the surface morphology of the films. It was also thought that the magnetic field might increase the surface roughness.

\section{EXPERIMENTAL PART}

In this paper, the chronoamperometry method of electrodeposition was utilized to deposit polycrystalline $\mathrm{CdS}$ thin films. The electrodepositions were carried out by using an IVIUM-Vertex potentiostat/galvanostat device. A three-electrode system consisting of a silver/silver chloride saturated calomel electrode as a reference electrode, an indium tin oxide (ITO) coated glass substrate as a working electrode and a platinum wire as a counter electrode was used. Before the depositions, ITO-coated substrates were washed with acetone and deionized water, respectively, and then, were left to dry in room conditions. The final solutions consisted of aqueous solutions of $0.2-\mathrm{M} \mathrm{CdCl}_{2}$ and $0.01-\mathrm{M} \mathrm{Na}_{2} \mathrm{~S}_{2} \mathrm{O}_{3}$. Besides, the $\mathrm{pH}$ values of the final solutions were adjusted to 3 by using $5 \%$ of volume fractions of $\mathrm{HCl}$ (Hydrochloric acid). The deposition time and the

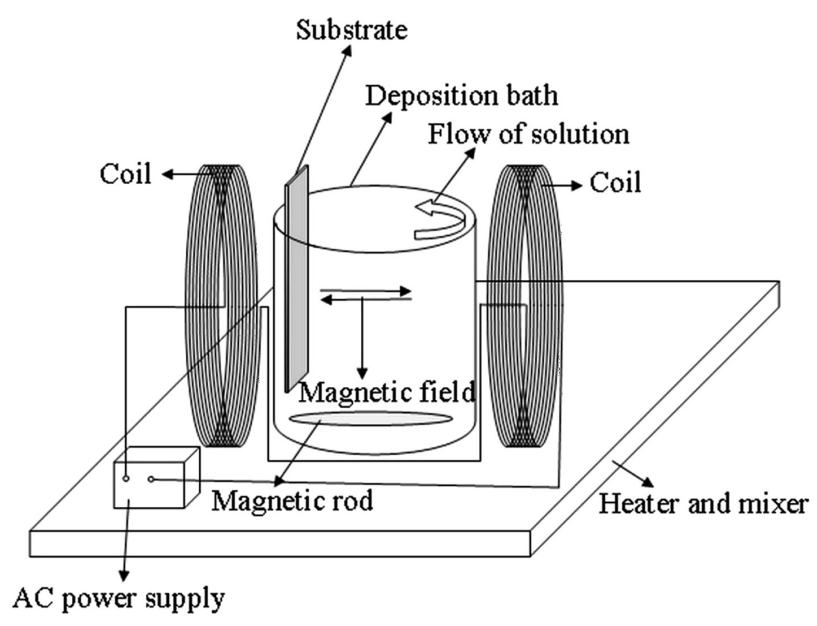

Figure 1: Scheme of deposition mechanism cathodic potential were fixed at $90 \pm 2{ }^{\circ} \mathrm{C}, 2700 \mathrm{~s}$ and $-0.6 \mathrm{~V}$, respectively. The final solutions were stirred at $600 \mathrm{~min}^{-1}$ by a heater/stirrer. In one experiment named B0, the external magnetic field was not applied, but in the other experiments, the external magnetic field was applied as is in the study ${ }^{5}$ previously given in Figure 1. The magnitude and frequency of the magnetic field were chosen as $3.25 \mathrm{mT} 25 \mathrm{~Hz}, 3.25 \mathrm{mT} 50 \mathrm{~Hz}, 6.5 \mathrm{mT} 25 \mathrm{~Hz}$ and $6.5 \mathrm{mT} 50 \mathrm{~Hz}$, which were named B1, B2, B3 and $\mathrm{B} 4$, respectively. The tabulated experimental conditions are given in Table 1. At the end of the depositions, all the samples were washed with deionized water and were left to dry in room conditions.

Table 1: Deposition conditions of the CdS films

\begin{tabular}{|c|c|c|c|c|c|}
\hline Experiments & B0 & B1 & B2 & B3 & B4 \\
\hline $\begin{array}{l}\text { Concentrationof } \\
\mathrm{CdCl}_{2}(\mathrm{M})\end{array}$ & 0.2 & 0.2 & 0.2 & 0.2 & 0.2 \\
\hline $\begin{array}{l}\text { Concentration } \\
\mathrm{Na}_{2} \mathrm{~S}_{2} \mathrm{O}_{3}(\mathrm{M})\end{array}$ & 0.01 & 0.01 & 0.01 & 0.01 & 0.01 \\
\hline Deposition time (sec) & 2700 & 2700 & 2700 & 2700 & 2700 \\
\hline Cathodic potential (V) & -0.6 & -0.6 & -0.6 & -0.6 & -0.6 \\
\hline Temperature $\left({ }^{\circ} \mathrm{C}\right)$ & $90 \pm 2$ & $90 \pm 2$ & $90 \pm 2$ & $90 \pm 2$ & $90 \pm 2$ \\
\hline $\mathrm{pH}$ & 3 & 3 & 3 & 3 & 3 \\
\hline $\begin{array}{l}\text { Magnitude of magnetic } \\
\text { field }(\mathrm{mT})\end{array}$ & 0 & 3.25 & 3.25 & 6.5 & 6.5 \\
\hline Frequency $(\mathrm{Hz})$ & 0 & 25 & 50 & 25 & 50 \\
\hline
\end{tabular}

For determining the structural and optical properties, PANalytical Empyrean XRD (X-ray diffractometer) and JASCO V-530 UV-vis (ultraviolet-visible) were used. FTIR analyses were conducted with a Perkin Elmer Spectrum 100 spectrophotometer. The surface morphologies were performed using a Zeiss SUPRA 40VP SEM (scanning electron microscope).

\section{RESULTS AND DISCUSSION}

\subsection{Structure of the CdS}

The currents versus time were recorded by devices, and these results were divided to surface area and, thus, the current densities were obtained. The plots of calculated current densities versus time are given in Figure 2. It is obvious in Figure 2 that the current densities of the films obtained under the magnetic field were lower than that of the other films. It might have resulted from the magnetic field scattering the ions in the solutions and, therefore, might reduce the current densities. In a previous study, ${ }^{5}$ the magnetic field reduced current densities. In this case, it can be said that this result matches with the literature. Thus, it can be said that the magnetic field affects the reaction rate. Current densities are also used to calculate the film thicknesses given in Equation 4.

$$
d=\frac{j M t}{n F \rho}
$$




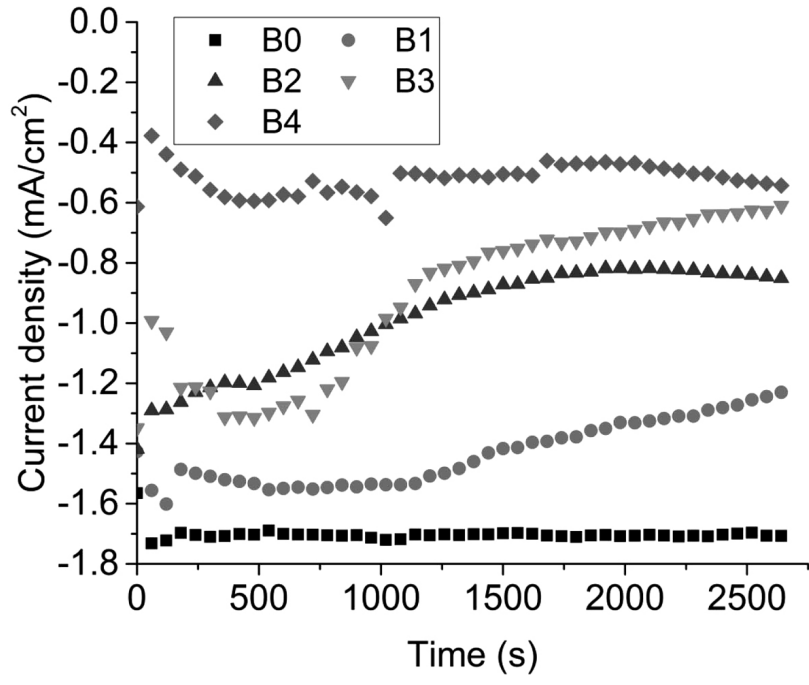

Figure 2: Calculated current densities of the CdS films, B0 $(0 \mathrm{~Hz}, 0 \mathrm{mT})$, B1 $(25 \mathrm{~Hz}, 3.25 \mathrm{mT}), \mathrm{B} 2(50 \mathrm{~Hz}, 3.25 \mathrm{mT}), \mathrm{B} 3(25 \mathrm{~Hz}, 6.50 \mathrm{mT}), \mathrm{B} 4$ $(50 \mathrm{~Hz}, 6.50 \mathrm{mT})$

where $d$ is the film thickness, $M$ is the molecular weight $(\mathrm{g}), J$ is the current density $\left(\mathrm{mA} / \mathrm{cm}^{2}\right), t$ is the deposition time (s), $\rho$ is the CdS density $\left(4.84 \mathrm{~g} / \mathrm{cm}^{3}\right), F$ is the Faraday constant $(96500 \mathrm{C})$ and $n$ is the number of electrons. ${ }^{2}$ It is unlikely that the current efficiency is $100 \%$ for these calculations. Therefore, the thicknesses were also calculated with the gravimetric method and the thicknesses obtained by using these two methods are given in Table 2. When the magnitude and frequency of the magnetic field were increased, the thicknesses of the films decreased from $712 \mathrm{~nm}$ to $215 \mathrm{~nm}$. This was an expected result due to the fact that the scattering of ions in the solutions was increased.

Table 2: Structural results of the CdS films

\begin{tabular}{|l|c|c|c|c|c|}
\hline \multicolumn{1}{|c|}{ Experiment } & B0 & B1 & B2 & B3 & B4 \\
\hline $\begin{array}{l}\text { Thickness } \\
\text { gravimetric }(\mathrm{nm})\end{array}$ & 413 & 372 & 324 & 301 & 204 \\
\hline $\begin{array}{l}\text { Thickness } \\
\text { calculated (nm) }\end{array}$ & 712 & 598 & 408 & 377 & 215 \\
\hline Crystallite size & $35 \mathrm{~nm}$ & $33 \mathrm{~nm}$ & $27 \mathrm{~nm}$ & $18 \mathrm{~nm}$ & $15 \mathrm{~nm}$ \\
\hline Band gap (eV) & 2.30 & 2.35 & 2.46 & 2.60 & 2.65 \\
\hline
\end{tabular}

In the electrodeposition, precipitation is carried out only on the surface of the substrate. The amount of precipitation of $\mathrm{CdS}$ on the surface of the substrate is negligible according to the amount of $\mathrm{Cd}$ and $\mathrm{S}$ ions in the solution. Therefore, the variation of the concentration of $\mathrm{Cd}$ in the solution cannot be accurately measured by using atomic absorption spectroscopy. Under these conditions, if $d^{*} \rho / t_{\text {total }}$ is calculated, the crystal growth rate (reaction rate) can be calculated from Equation 4 . The calculated reaction rates are $\left(7.43 \times 10^{-8}, 6.67 \times 10^{-8}\right.$, $5.81 \times 10^{-8}, 5.40 \times 10^{-8}$ and $\left.3.66 \times 10^{-8}\right) \mathrm{g} / \mathrm{cm}^{2} \mathrm{~s}$ obtained in B0, B1, B2, B3 and B5 respectively.

Figure 3 shows XRD patterns of the films and the patterns related to the hexagonal structure of the $\mathrm{CdS}$ crystal. It is important because of the fact that there were no cubic structured $\mathrm{CdS}$ films. If the $\mathrm{CdS}$ had been formed with chemical bath deposition process, there would be cubic crystals of $\mathrm{CdS}$. The peak intensities were increased as the film thicknesses decreased. This is a result that could be seen due to the fact that when the reaction rates were reduced by external effects, the film thicknesses decreased and thus good crystallized films could be obtained. There was a strong relationship between the reaction rate and good crystallization. These results match with the literature. ${ }^{6-8}$

The preferred orientation of the films can be calculated by using the texture coefficients as given in Equation (5), ${ }^{9}$

$$
T C=\frac{\frac{I_{(\mathrm{hkl})}}{I_{0(\mathrm{hkl})}}}{\frac{1}{\mathrm{~N}} \sum_{N} \frac{I_{(\mathrm{hkl})}}{I_{0(\mathrm{hkl})}}}
$$

where $I_{(\mathrm{hkl})}$ is the measured intensity of a plane (hkl), and $I_{0(\mathrm{hkl})}$ is the standard intensity of the plane (hkl) given in the ASTM card. The texture coefficients are given in Table 3 .

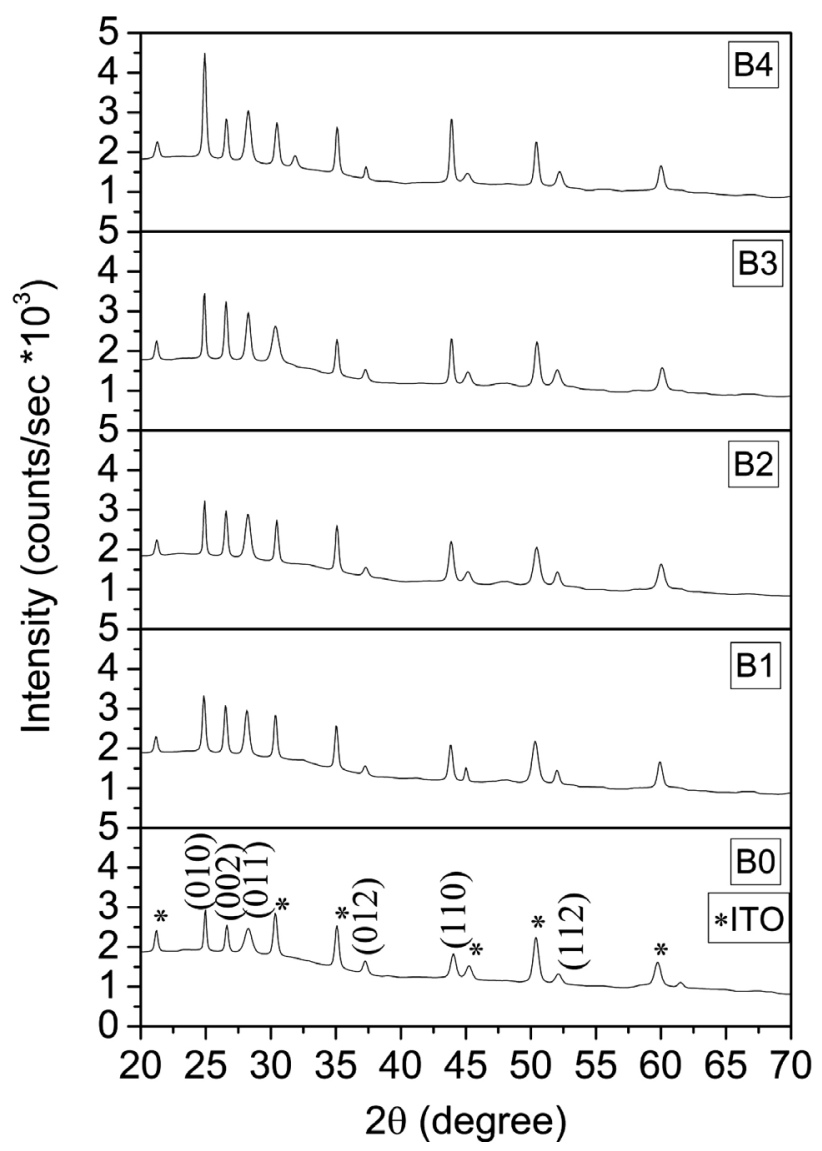

Figure 3: XRD patterns for CdS films, B0 $(0 \mathrm{~Hz}, 0 \mathrm{mT}), \mathrm{B} 1(25 \mathrm{~Hz}$, $3.25 \mathrm{mT}), \mathrm{B} 2(50 \mathrm{~Hz}, 3.25 \mathrm{mT}), \mathrm{B} 3(25 \mathrm{~Hz}, 6.50 \mathrm{mT}), \mathrm{B} 4(50 \mathrm{~Hz}$, $6.50 \mathrm{mT}$ ) 
Table 3: Texture coefficients of the CdS films

\begin{tabular}{|c|c|c|c|c|c|}
\hline Experiments & B0 & B1 & B2 & B3 & B4 \\
\hline T.C.(010) & 1.38 & 1.13 & 1.15 & 1.20 & 1.63 \\
\hline T.C.(002) & 1.16 & 1,35 & 1,30 & 1.34 & 0.91 \\
\hline T.C.(011) & 0.46 & 0.52 & 0.53 & 0.47 & 0.46 \\
\hline
\end{tabular}

The following equation was used to calculate the crystallite sizes according to the (010) plane and they are given in Table 2.

$$
C S=\frac{0.089 \cdot 180 \cdot \lambda}{314 \cdot \beta \cdot \cos \theta_{\mathrm{C}}} \mathrm{nm}
$$

where $\lambda$ is the wavelength of the $\mathrm{X}$-ray radiation $(0.154056 \mathrm{~nm}), 2 \theta$ is the position of the peak centre, $\beta$ is the full width at the half maximum of peak height (in degrees). The $\beta$ and $2 \theta$ values were calculated by fitting the XRD peak profile to a Lorentzian shape. ${ }^{10}$ The crystallite sizes increased as the film thicknesses increased. This was an expected result. If the growth rate of the crystal increases, the size of the crystallite naturally increases.

\subsection{Optical features of the CdS}

The recorded absorbance measurements versus wavelength are given in Figure 4. The wavelength was started at $600 \mathrm{~nm}$ and ended at $400 \mathrm{~nm}$. This range was sufficient due to the fact that a sharp increasing of absorbance takes place at about $500 \mathrm{~nm}$ for CdS thin films. The absorbance measurements are used to estimate the optical energy band gap of the films. The absorption coefficient can be described as a function of the photon energy, as is given in Equation 7 for the direct allowed transition

$$
(\alpha h v)^{2}=A\left(h v-E_{g}\right)
$$

where $A$ is the constant, $E_{\mathrm{g}}$ is the band gap, $v$ is the frequency of the incident photon and $\mathrm{h} v$ is the photon

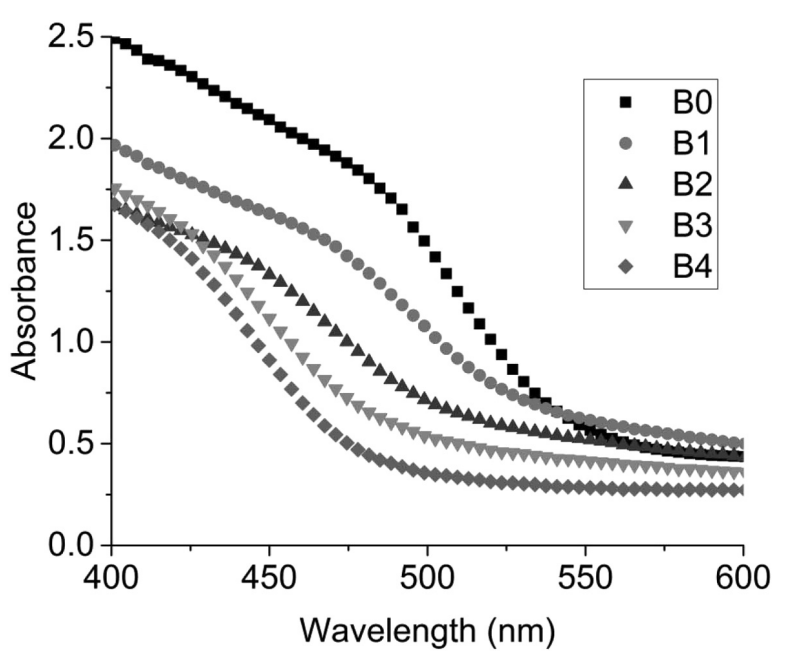

Figure 4: Recorded absorbance measurements of CdS films versus wavelength B0 $(0 \mathrm{~Hz}, 0 \mathrm{mT}), \mathrm{B} 1(25 \mathrm{~Hz}, 3.25 \mathrm{mT}), \mathrm{B} 2(50 \mathrm{~Hz}, 3.25$ $\mathrm{mT}), \mathrm{B} 3(25 \mathrm{~Hz}, 6.50 \mathrm{mT}), \mathrm{B} 4(50 \mathrm{~Hz}, 6.50 \mathrm{mT})$

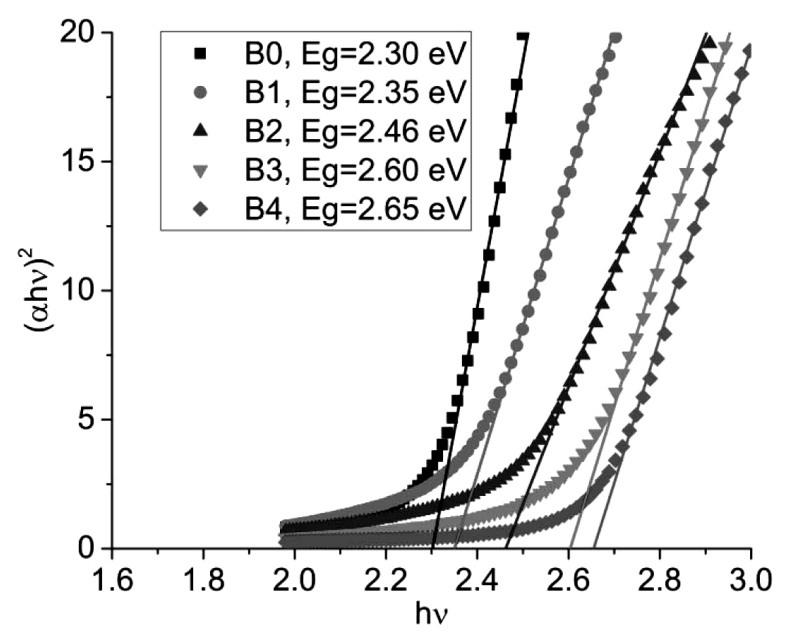

Figure 5: Typical Tauc plots for deposited CdS films, B0 (0 Hz, $0 \mathrm{mT})$, B1 $(25 \mathrm{~Hz}, 3.25 \mathrm{mT}), \mathrm{B} 2(50 \mathrm{~Hz}, 3.25 \mathrm{mT}), \mathrm{B} 3(25 \mathrm{~Hz}, 6.50 \mathrm{mT}), \mathrm{B} 4$ $(50 \mathrm{~Hz}, 6.50 \mathrm{mT})$

energy. ${ }^{11}(\alpha h v)^{2}$ versus $h v$ plots are drawn and $E_{\mathrm{g}}$ values are estimated by extrapolating the linear segment of each plot. ${ }^{12}$ In this study $(\alpha h v)^{2}$ versus $h v$ plots and estimated band gaps are given in Figure 5 and Table 2, respectively. The energy band gaps of the films increased from $2.30 \mathrm{eV}$ to $2.65 \mathrm{eV}$, proportionally, depending on the increasing of the magnitude and the frequency of the external magnetic field. In fact, the magnetic field reduced the reaction rates and, thus, the crystallite sizes. There is a relation between the crystallite size and energy band gap; therefore, the band gaps increased from $2.30 \mathrm{eV}$ to $2.65 \mathrm{eV}$ as the crystallite size decreased from $35 \mathrm{~nm}$ to $15 \mathrm{~nm}$. When the atoms are merged in order to form a bulk, the orbits split and these splitting orbits generate bands. When the numbers of atoms are increased, the width of the bands increases and thus the band gap reduces.

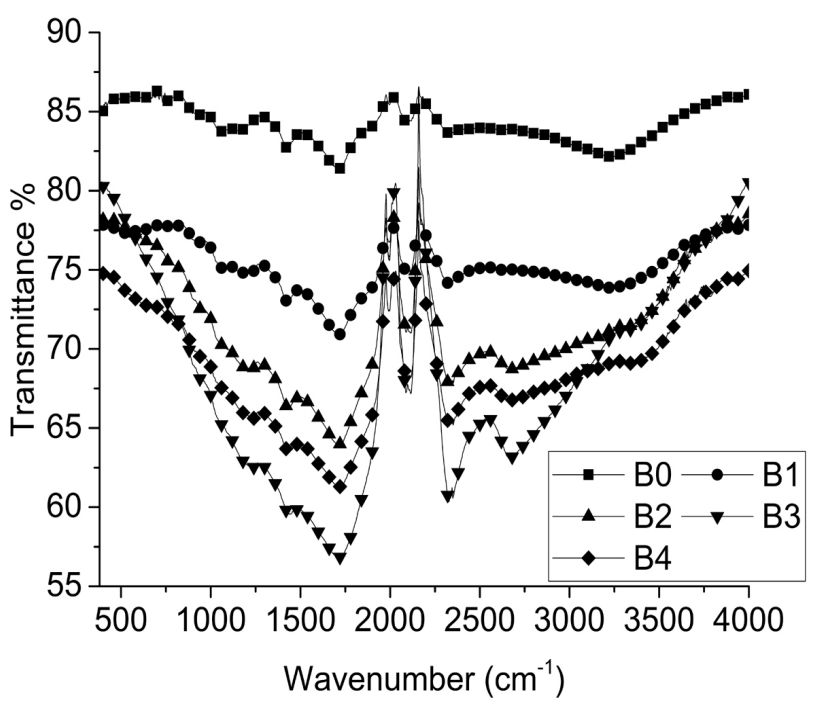

Figure 6: Typical FTIR measurements of the CdS films, B0 (0 Hz, $0 \mathrm{mT})$, B1 $(25 \mathrm{~Hz}, 3.25 \mathrm{mT}), \mathrm{B} 2(50 \mathrm{~Hz}, 3.25 \mathrm{mT}), \mathrm{B} 3(25 \mathrm{~Hz}, 6.50 \mathrm{mT}), \mathrm{B} 4$ $(50 \mathrm{~Hz}, 6.50 \mathrm{mT})$ 


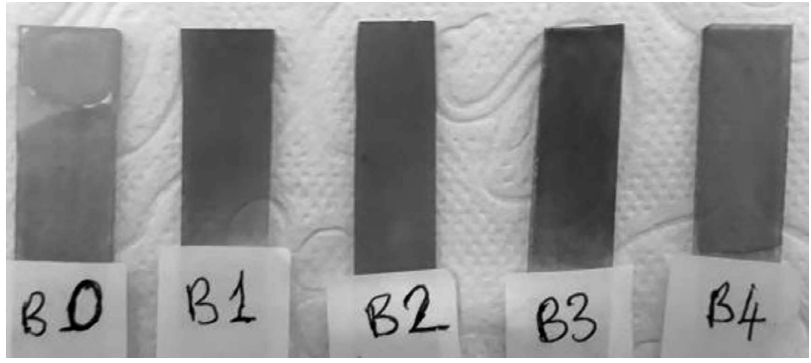

Figure 7: Photographs of the CdS films, B0 $(0 \mathrm{~Hz}, 0 \mathrm{mT}), \mathrm{B} 1(25 \mathrm{~Hz}$, $3.25 \mathrm{mT}), \mathrm{B} 2(50 \mathrm{~Hz}, 3.25 \mathrm{mT}), \mathrm{B} 3(25 \mathrm{~Hz}, 6.50 \mathrm{mT}), \mathrm{B} 4(50 \mathrm{~Hz}$ $6.50 \mathrm{mT})$

\subsection{FTIR analysis of the CdS}

Fourier transform infrared spectroscopy (FTIR) spectrums versus wavenumber are given in Figure 6. The weak peak around at $3400 \mathrm{~cm}^{-1}$ has been assigned to the O-H stretching of the absorbed water on the surface of the CdS. ${ }^{13}$ The presence of water was also confirmed by its bending vibration observed at approximately $1680 \mathrm{~cm}^{-1}$. The peak at $1400 \mathrm{~cm}^{-1}$ was possibly due to the stretching vibrations of the sulphate group. ${ }^{14}$ Small and weak peaks at between $400 \mathrm{~cm}^{-1}$ and $470 \mathrm{~cm}^{-1}$ were related to the $\mathrm{Cd}-\mathrm{S}$ bond stretching $(\mathrm{CdS}$ nanoparticles). ${ }^{15}$

The transmittance values obtained from the FTIR spectra decreased as the magnitude of the magnetic field increased. These results show that the surface area increases. Thus, it can be said that the surface roughness of the films increased. But this result should be supported by estimating SEM images.
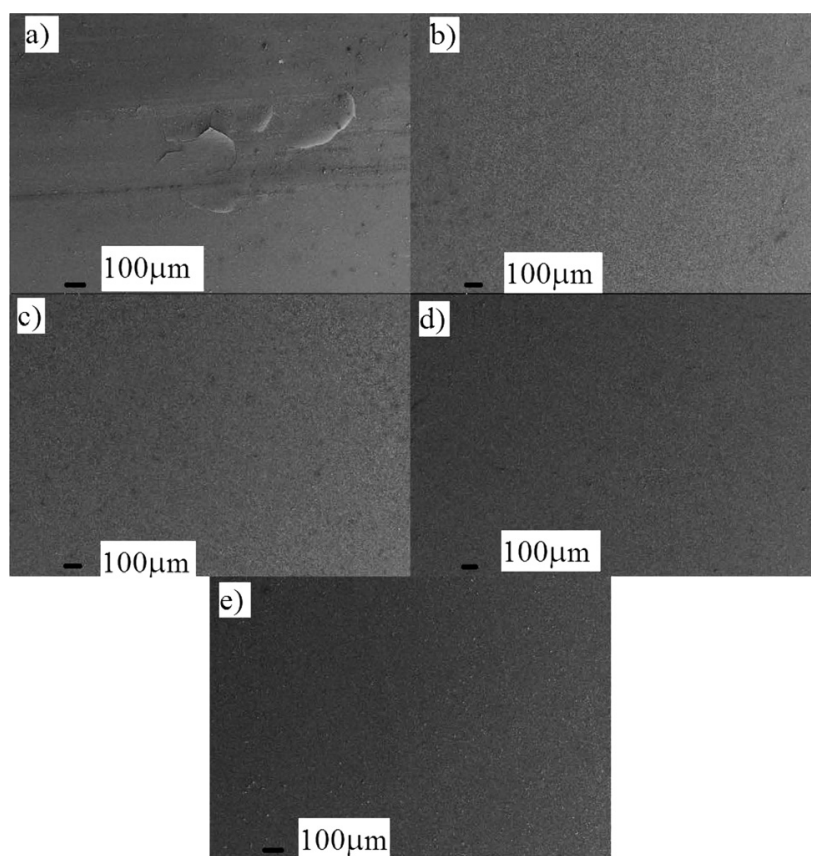

Figure 8: 100× magnified top view SEM images of the CdS films, a) $0 \mathrm{~Hz}, 0 \mathrm{mT}$, b) $25 \mathrm{~Hz}, 3.25 \mathrm{mT}$, c) $50 \mathrm{~Hz}, 3.25 \mathrm{mT}$, d) $25 \mathrm{~Hz}, 6.50$ $\mathrm{mT}$, e) $50 \mathrm{~Hz}, 6.50 \mathrm{mT}$

\subsection{Visual appearance of the CdS}

Figure 7 shows the top view photos of the CdS thin films. The surface of the film obtained without magnetic field (B0) looked very compact and homogenous. Besides, it seemed lighter than the others. This lighter surface might have been caused by the low surface roughness. The surfaces of the films obtained under external magnetic field (B1, B2, B3 and B4) appeared very homogenous and were darker. It was concluded that the low reaction rate might have caused the homogenous surfaces. Besides, ha igh surface roughness might cause a darker surface.

\subsection{Morphology of the CdS}

For the surface morphology of the films a SEM (scanning electron microscope) was used. The working distance was $8 \mathrm{~mm}$ and the operating mode was secondary-electron imaging (SEI). SEM images that are magnified approximately 100 times are not usually given in the literature. However, some cracks and voids appear only in low-magnification images, such as in this study. In Figure 8, 100x magnified SEM images are seen. There are cracks on the surface image of the film grown without magnetic field given in Figure 8a. A high crystal growth rate might cause cracks because of the fact that the rapid expansion of nucleons might cause cracks in the crystals. The surface images of the films produced by applying an external magnetic field seemed quite compact and there were no cracks and voids on these surfaces. Figure 9 shows the 50000× magnified surface images of the CdS films. Pinholes and voids were seen

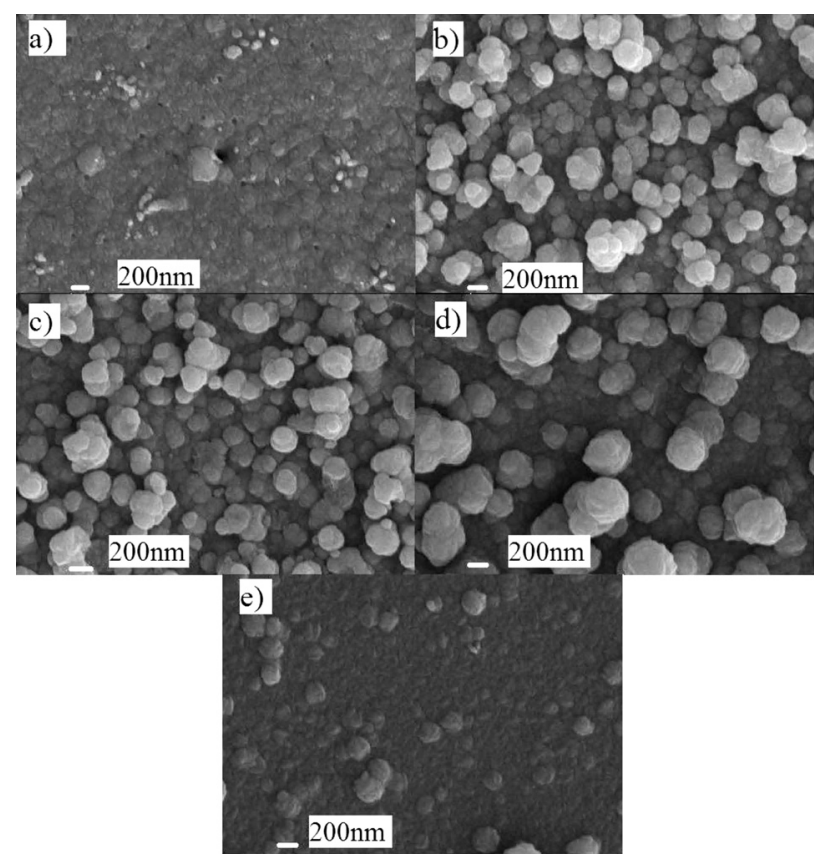

Figure 9: 50,000× magnified top view SEM images of the CdS films, a) $0 \mathrm{~Hz}, 0 \mathrm{mT}$, b) $25 \mathrm{~Hz}, 3.25 \mathrm{mT}$, c) $50 \mathrm{~Hz}, 3.25 \mathrm{mT}$, d) $25 \mathrm{~Hz}$, $6.50 \mathrm{mT}$, e) $50 \mathrm{~Hz}, 6.50 \mathrm{mT}$ 
on the surface of the films (Figure 9a) produced without a magnetic field. But, there were no clusters on this surface. This situation explains why this surface seemed lighter. On the other hand, the surfaces of the other films had no pinholes, voids and cracks but there were plenty of clusters on these surfaces. The low crystal growth rate might prevent cracks and pinholes, but scattering ions by magnetic field might cause the nucleation to begin in many places. And, thus, there might be plenty of clusters. The increased surface area of these films might make them suitable for sensors.

\section{CONCLUSIONS}

In this paper, electrodeposition was utilized for the growth of CdS thin films and, in some of the experiments, an external magnetic field was applied during the deposition. It was understood from the film thicknesses and current densities that the magnetic field reduced the reaction rate by about half. The alternating magnetic force may cause the scattering of ions in the final solutions and these scatterings may cause crystal growth in many places. Thus, a lot of bulk with a low crystal size may be formed. This result may explain the high roughness of the surfaces. The structural analyses were performed with XRD. The XRD patterns revealed that all the films were formed in the hexagonal structure. Besides, reducing the reaction rate increased the good crystallization and decreased the crystallite size from $35 \mathrm{~nm}$ to $15 \mathrm{~nm}$, depending on the magnitude and the frequency of the magnetic field. As there is a strong relationship between the crystallite size and the band gap, the band gaps of the films varied between $2.30 \mathrm{eV}$ and $2.65 \mathrm{eV}$, depending on the decreasing crystallite sizes. The magnetic field and, hence, the reaction rate were also significant influences on the film morphology. Decreasing the reaction rate prevented cracks, pinholes and voids, and caused the surfaces to become homogenous. Besides, the scattering of ions by the magnetic field was thought to increase the surface roughness. The increasing surface roughness caused increasing surface area and, thus, it might be suitable for sensors.

\section{REFERENCES}

${ }^{1}$ E. O. Okechukwu, D. N. Okoli, Optical and structural properties of electrodeposited CdS/ZnS compound thin films and their possible applications, J. Mater. Sci. Appl., 1 (2015), 282-291

${ }^{2}$ M. Fathy, A. El-Hady, B. Kashyout, S. Elyamny, G. D. Roston, A. Bishara, Effect of $\mathrm{CdCl} 2$ concentration and heat treatment on electrodeposited nano-crystalline CdS thin films from non aqueous solution, Int. J. Electrochem. Sci., 9 (2014), 6155-6165

${ }^{3}$ M. N. Mammadov, A. Sh. Aliyev, M. El-rouby, Electrodeposition of cadmium sulfide, Int. J. Thin Film Sci. Tec., 1 (2012), 43-53

${ }^{4}$ M. A. S. Aliyev, M. El-rouby, Electrochemical studies on the cathodic electrodeposition of n-type semiconductor CdS thin film from thiosulfate acidic aqueous solution, Int. J. Thin Film Sci. Tec., 2 (2013), 195-205, doi:10/12785/ijtfst/020305

${ }^{5}$ B. Altiokka, A. Kiyak Yildirim, Effects of external alternating magnetic field on $\mathrm{ZnO}$ films obtained by electrodeposition, Arab. J. Sci. Eng., 41 (2016), 2345-2351, doi:10.1007/s13369-015-1980-7

${ }^{6}$ O. Calzadilla, E. Hernández, E. M. Larramendi, F. Caballero-Briones, M. Zapata-Torres, M. Meléndez-Lira, A. Zapata-Navarro, Chemical bath deposited CdS films using magnetic treated solutions, phys. stat. sol (b), 242 (2005) 1933-1936, doi:10.1002/pssb. 200461806

${ }^{7}$ J. G. V. Luna, A. Zehe, O. Zelaya-Angel, Chemical CdS thin-film deposition influenced by external electric and magnetic fields, Crys. Res. Tech., 34 (1999) 949-958

${ }^{8}$ J. G. Vazquez-Luna, A. Zehe, M. P. Trujillo-Garcia, O. Starostenko, Formation of CdS thin films in a chemical bath environment under the action of an external magnetic field, Rus. J. Electrochem., 36 (2000) 893-897

${ }^{9}$ H. Soetedjo, B. Siswanto, I. Aziz, S. Sudjatmoko, Low resistivity of $\mathrm{Cu}$ and $\mathrm{Fe}$ doped $\mathrm{PbS}$ thin films prepared using dc sputtering technique, J. Non-Oxid Glasses., 9 (2017) 55-63

${ }^{10}$ R. N. Bhowmik, M. Nrisimha Murty, E. Sekhar Srinadhu, Magnetic modulation in mechanical alloyed $\mathrm{Cr} 1.4 \mathrm{Fe} 0.6 \mathrm{O} 3$ oxide, PMC Phys. B, 1 (2008) 1-18, doi:10.1186/1754-0429-1-20

${ }^{11}$ G. Sasikala, R. Dhanasekaran, C. Subramanian, Electrodeposition and optical characterisation of CdS thin films on ITO-coated glass, Thin Solid Films, 302 (1997) 71-76, doi:10.1016/S00406090(96)09582-X

${ }^{12}$ H. Y. R. Atapattu, D. S. M. De Silva, K. A. S. Pathiratne, I. M. Dharmadasa, Effect of stirring rate of electrolyte on properties of electrodeposited CdS layers, J. Mater. Sci: Mater. Electron., 27 (2016) 5415-5421, doi:10.1007/s10854-016-4443-3

${ }^{13}$ R. Duchaniya, Optical studies of chemically synthesis CdS nanoparticles, Int. J. Min. Eng. Meth. Mech. Eng., 2 (2014) 2320-4060

${ }^{14}$ A. U. Ubale, Structural, optical and electrical properties of nanostructured CdS:CuS composite thin films grown by CBD method, Int. J. Mater. Chem., 2 (2012) 165-172, doi:10.5923/j.ijmc. 20120204.09

${ }^{15}$ N. Qutub, S. Sabir, Optical, thermal and structural properties of CdS quantum dots synthesized by a simple chemical route, Int. J. Nanosci. Nanotechnol., 8 (2012) 111-120 